\title{
INSTRUCTIONS
}

\author{
FOR
}

COLLECTING, REARING, AND

PRESERVING

\section{BRITISH INSECTS;}

- ALSO FOR

COLLECTING AND PRESERVING

BRITISH CRUSTACEA \& SHELIS;

TOGETHEK WITH A DESCRIPTION OE

\section{ENTOMOLOGICAL APPARATUS:}

TO WHICH IS ADDED, A LIST OF NEW AND RARE SPECIES OF INSECTS, \&C. WITH THEIR LOCALITIES AND TIMES OF APPEARANCE.

INTENDED FOR COLLECTORS, AND RESIDENTS IN THE COUNTRY.

WITH AN ILLUSTRATIVE PLATE.

BX

ABEL INGPEN, A.L.S.

"Magna opera JеноV , explorata omnibus volentibus ea."

Ps. cxi. 2.

LONDON :

JAMES BULCOCK, 163, STRAND.

1827.

Price Three Shillings and Sixpence. 



\section{INSTRUCTIONS}

FOR

COLLECTING, REARING, AND

PRESERVING

\section{BRITISH INSECTS; \\ - ALSO FOR}

COLLECTING AND PRESERVING

BRITISH CRUSTACEA \& SHELLS;

TOGETHEH WITH A DESCRIPTION OF

\section{ENTOMOLOGICAL APPARATUS:}

TO WHICH IS ADDED, A LIST OF NEW AND RARE SPECIES OF INSECTS, \&C. WITH THEIR LOCALITIES AND TIMES OF APPEAHANCE.

INTENDED FOR COLLECTORS, AND RESIDENTS IN THE COUNTRY.

WITH AN ILLUSTRATIVE PLATE.

BX

ABEL INGPEN, A.L.S.

"Magna opera JEHov $\boldsymbol{x}$, explorata omnibus volentibus ea." Ps. cxi. 2.

\section{LONDON :}

JAMES BULCOCK, 163, STRAND. 1827.

Price Three Shillings and Sixpence. 


\section{Smithsonian Institution Libraries}

Purchased from the CULLMAN ENDOWMENT 



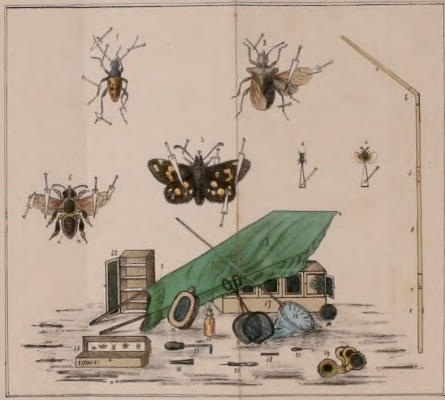



LONDON :

C. SMITH, PRINTER, ONE BELl YARD, STRAND. 
JAMES FRANCIS STEPHENS, ESQ. F.L.S

\&c. \&c.

\section{THIS TRIFLE IS INSCRIBED,}

IN RESPECT FOR HIS VIRTUES,

IN ADMIRATION OF HIS TALENTS,

AND IN GRATITUDE FOR MANY FAVORS;

By his very obliged Servant,

THE AUTHOR,

London,

February 28th, 182\%. 



\section{ADVERTISEMENT.}

The design of the following pages is to supply instructions, in a detached form, for collecting and preserving British Insects, Crustacea and Shells; not only for the Student, but also to distribute to persons residing in the Country, who wish to oblige their Entomological friends by collecting, or employing others to collect for them. The want of such a work, for distribution, has been long felt, and it is hoped that the present will be found useful for the purpose. It has been the chief aim of the author to make the instructions as full and as simple as possible, and many useful hints and directions will be found peculiar to this work.

To those who wish for information as to the localities, habitats, and periods of appearance, of particular British Insects, \&c., the valuable calendar in "Samouelle's Entomolo- 


\section{vi}

gist's Useful Compendium," will be found of great assistance. And for information as to their natural history, classification, and arrangement, the Student is referred to Kirby and Spence's admirable "Introduction to Entomology;" Curtis's " British Entomology," with beautiful plates, now in the course of publication; and the forthcoming "Sysiematic Catalogue of British Insects," and "Illustrations of British Entomology," describing all the species, by Mr. Stephens; all of which are indispensible. 


\section{DESCRIPTION OF THE PLATE.}

FIG. 1. Pachyta 6-punctata, (Capricorn beetle.)

2. Pentatoma rufipes, (field bug.)

3. Hesperia paniscus, (scarce skipper butterlly.)

4. Stylops Melittæ, p. 43.

5. Melittæ nigroænea, (wild bee.)

6. Dyschirius gibbus*.

7. A clap net complete, described, p. 2. a. the leather hinge, $b$. the bag,

8. A net rod, $a$, the cross piece; $b$, the augulated ferrule; $c$. the straight ferrule; $d$. the notch or joint; $e$. the staple to which the strings are tied.

9. Forceps, p. 4.

10. A ring net, p. 6 .

11. A digger, p. 7 .

12. A water net, p. 6.

13. A phial, p. 8 .

14. A pair of pliers, p. 8.

15. A pocket collecting hox, p. 9.

16. A pocket lavva box, p. 10.

17. A breeding cage, p. 10 .

18. A quill, p. 16.

19. A pocket magnifier, p. 16 .

20. and 21. Setting needles, p. 17.

22. Setting board case, p. 18 .

* 'The above insects are drawn rather larger than life. 



\section{CON'TENTS.}

Introduction $\ldots \ldots \ldots \ldots \ldots \ldots \ldots$ xi

Description of Apparatus, Cabinets, and mode of arranging Insects....... 1 Instructions for Collecting Insects. Winter. 23 Ditto................. Spring. 33 Ditto.................Summer. 45 Ditto..................... 50 Local Habitats . . . . . . . . . . . . . . 55

Peculiar Methods of Collecting Insects . . 62 Instructions for Killing and Preserving

Insects, \&c............. 68

Instructions for Collecting and Preserving Crustacea............. 82 Instructions for Collecting and Preserving Shells............... 84 List of New Species of Insects, \&c. . . . 87 



\section{INTRODUCTION.}

THE contemplation of the works of the Creator is the highest delight of the rational mind. In them we read, as in a volume fraught with endless wonders, the unlimited power and goodness of that BEING, who, in the formation of Atoms, and of Worlds, has alike displayed unfathomable Wisdom.

There are few objects in Nature which raise the mind to a higher degree of admiration, than the Insect world. Their im. mense numbers - endless variety of form - astonishing metamorphoses - exceeding beauty-the amazing minuteness of some, and the complex and wonderful organization of others, far exceeding that of the highest ranks of the creation-all tend to prove an 


\section{xii}

Almighty artificer, and inspire astonishment and awe!

But in reviewing the amazing endowments of these endless tribes of beings, which administer so much to the gratification of our mental and ocular faculties, the great utility, and important advantages derived from many of them, have also another claim upon our regard. The delicious luxury furnished by the bee, and the beautiful dye of the coccus: the materials for an exquisite fabric, prepared by the silk worm, which gives employment to millions! and the ingredient produced by the gall-fly, to which mankind is deeply indebted for the promulgation of knowledge! are all real benefits. But from others, lessons of industry and economy; virtue and morality; perfection in various arts, and even civil government, may be learned; and, accordingly, they have been held up as models of conduct, and referred to for instruction in wisdom from the days of Solomon. 


\section{xiii}

These few facts may be sufficient to prove, that, so far from entomology being a frivolous amusement, (as some have ignorantly asserted) or suffering in importance by comparison with other studies, it deserves, what it will one day attain, to stand in the very foremost rank of Natural Science! For it furnishes more links, perhaps, than any other Science, to prove the existence of

"The mighty chain of beings, lessening down From Infinite Perfection to the brink of dreary Nothing, desolate abyss !"

"Organized nature is a complicated chain of beings, of which chain, each species forms a link. Every new species added to our list, serves thus to increase our knowledge of this stupendous system-a system that ought to excite in every breast the most intense interest; not merely as one of the works of our Creator, but as that particular work of the Divine Hand, which has been designed with direct reference to ourselves. $\Lambda$ minute 


\section{xiv}

beetle, therefore, which of itself scarcely raises a thought in our minds, beyond what may originate in its splendour of colour, or its eccentricity of form, becomes absolutely important when described in reference to its fellows." Annulosa Javanica.

The following instructions are mereiy a stepping-stone to entomology, the study of which will be found a "grand panacea for the tedium vita," which is so often felt by those whose time is entirely at their own disposal; and an interesting relaxation for those engaged in severer studies. It furnishes a wide field for observation, and an innocent employment, peculiarly delightful and instructive; it is also an endless source of novelty and amusement, an incentive to exercise, and consequent health ; and gives a double zest to the enjoyment of the country. It is therefore much to be regretted, that this study, which tends so much to enlarge the understanding 
and render life at once innocent and happy, should not form a part of the education of youth; a period of life the best adapted for receiving correct impressions, and materials for strengthening the mental faculties. 



\section{DESCRIPTION OF APPARATUT,}

NECESSARY FOR

COLLECTING AND PRESERVING

I N S E C T S.

" 'THE collector when he makes an excursion should have three principal objects in view, for which he ought to be duly prepared. The first $s$ to find insects, the next is to catch them, and the last, when taken, to bring them safe home. In exploring their haunts, he must aiso recollect that some will be reposing; others feeding; others walking or running; others fiying ; others swimming; others lurling in various places of concealment, and in different states of existence."

* "Introduction to Entomology," Vol. iv. p. 515. 
It is necessary, therefore, that he should be provided with proper instruments to collect them, and to preserve them when collected The following is a description of the apparatus used by the London collectors: for the detail of which, the author is partly indebted to the works of Messrs. Kirby and Spence, and Mr. Samouelle.

A Cuap Net, (plate, fig. $\%$ ) is the first instrument in point of importance. This is similar to what is called a Bat-fowling net, and should be made of green or white gauze or muslin; the advantage of the latter colour is, that minute insects are sooner discovered than if the net were green, but a green net must be used for mothing. The net rods may be made of ash, hazel, or lance wood, but the latter is best. Each rod may be from four to five feet in length, (divided into three or four joints, for the convenience of carriage) round, and smooth, half an inch in diameter at the base, and gradually tapering: plate, fig. $S$, one of the rods complete; $a$, the cross-piece, which should be of 
cane, and made to fit into the angulated ferrule; $b$, the rod, which must have a ferrule riveted on to the upper part as at $c$; the joints should be made with a notch, as at $d$; which will prevent the upper part from twisting: $e$, a small staple, to which the net must be tied. When put together, care must be taken in fitting the joints to the brass tubes, that they are made exact, or otherwise they will be subject to shake, and continually come to pieces. The net, fig. $z$, must be bound entirely round with a broad welt, doubled to form a groove, into which the rods are to slip. In the angle of the upper part, a, a small piece of wash leather to form a hinge, must be sewed round the welt, divided and sewed in the middle, to prevent the cross pieces from slipping over each other: $b$, about six inches of the gauze turned up to form a bag, to the bottom of which must be sewed strings to tie round the rod and fasten to the staple.

When the net is used, the rods should be taken one in each hand, so as to keep it cxtended; and when it is brought fairly beyond 
the insect pursued, the two sticks must be brought quickly together, by which means the prey is easily captured. This net answers very effectively for taking even the minutest insect on the wing, as it may in an instant be opened and folded together. It is also useful for taking winged insects when at rest upon the ground, by simply spreading it over them. When beating into the net, it will be necessary to keep both sticks in the left hand, at the same time keeping the head of the net as wide open as possible. An open umbrella will, in general, be found convenient in the absence of a clap-net, for beating; particularly if the inside be lined with white cotton, and made to cover the whalebone. In the event of beating into an umbrella, the forceps should always remain within it, so as to be ready to be instantly used in catching a winged insect.

'The Forceps, (plate, fig. 9.) is an indispensible instrument. It should be made of iron or steel, and about seven inches and a half in length, the hoops of brass, or iron, painted to 
secure them from rust, about four inches in diameter, and nearly circular, the front part, $a$, being straight, in order to capture an insect settled on a wall or tree. The joint of the handle should be much nearer the rings for the finger and thumb, than to the hoops, or the instrument will not open well. An old pair of curling irons (having rings for the finger and thumb) might be made into very good handles. The hoops should be covered with fine gauze or net; the latter is best, as it will admit of the head of a pin being drawn through it. They are held and moved like a pair of scissors, and are extremely useful in taking bees, wasps, and other insects which inhabit sand banks, as well as any other insect at rest. If an insect be on a leaf, both leaf and insect must be inclosed in the forceps, and if settled on a flat surface, they are easily entrapped. If the insect be a butterfly, moth, or bee, the underside of the thorax (that part to which the wings and leg's are attached) should be sharply pressed; it may then be shaken into the hand, and pierced, or a pin passed through the thorax (as shewn plate, figs. 3 and 5.) while the 
insect is confined in the net; it should then be carefully taken out by the pin.

A Ring Net, (plate, fig. 10.) is merely a piece of very stout brass wire of three or four inches diameter, convenient for the pocket, and formed into a ring, having a small loop or handle. This ring should be covered with gauze or net. It will be found very useful to place over moths, settled on pales, trees, \&c. by which means they may be easily captured.

A Water Net. (plate, fig. 12.) The hoop of an angler's landing net will be found the best for this purpose, as it may be folded and carried in the pocket. The socket may be made to screw into a walking or beating stick ; and a brass cap made to screw over the female screw to keep the dirt out when not in use; and an extra joint to screw or fix in, which could be carried in the pocket. The bag should be made of coarse canvass, about a foot deep. This net is intended for taking water insects, and should be drawn well under the weeds and 
aing the margins of ponds, rivers, and ditches; and also among the mud at the bottom, and the contents carefully examined. It will also be found very uscful for brushing grass and weeds in fields, ditches, on banks, \&c. $\Lambda$ bag net made of green gauze, from two to three feet long, and fitted to the same hoop, may be made to serve various purposes. With it butterfles, moths, and other insects on the wing may be caught, and by giving it a twist the mouth may be completely closed, so as to prevent the escape of the captive. When fixed to a pole twenty or thirty fect long, Mr. Haworth considers it the best net for taking the Purple Emperor butterfly, (Apatura Iris) whose residence is generally on or near the tops of lofty oaks. It will also be found preferable to the water net, for pushing through grass, \&c. as, from its depth, flying insects cannot so readily escape. If the hoop of the water net should be considered too small, a piece of cane bent to the size required, and tied to the stick, will be a good substitute.

A Digime. (plate, fig. 11.) This should be 
made of steel, of from twelve to eighteen inches long, forked at the extremity, and fixed into a wooden handle. It is of great use in stripping bark from decayed trees, digging into rotten wood, round trees, \&c. As a companion to this instrument, a good strong clasp knife, having also a saw blade, will be found very useful.

A Phial, (plate, fig. 13.) or tin bottle, is very convenient in collecting beetles. In this bottle a tube should be introduced, and extended a little way down the bottle, to prevent the insects put into it from escaping; a phial with a quill passed through the cork, having a cork stopper to the quill, will be very useful for small insects. If spirits be put into the phials, only those beetles which are black or of a dark colour should be put into them.

Pliers, (plate, fig. 14.) for taking insects out of holes in trees, and from dung, roots of grass, \&c. A wet finger will also be found very useful in taking up insects when stationary or in motion. 
A Pochet Collectrag Box. (plate, fig. 15.) The collector should be furnished with a light deal or chip box of a convenient size for the pocket, lined at the top and bottom with cork, and covered with white paper; leaving a space of at least half an inch between the heads of the pins when the box is closed. In this box are to be placad those insects which are pierced, and which would be injured by remaining loose. The most useful kind of box is, however, made of deal or mahogany, conrenient as to size, with two hinges on one side, and made to open in the middle by pressing a little spring. This box, opened by the left hand, leaves the right at liberty to put in the insects*. These boxes are only fit for a single day's collecting, but if the collector be on an excursion for a longer period, he must furnish himself with the necessary quantity of store boxes, pins, braces, \&c. Sc. Store boxes may be male upon the principle of back-gammon boards, of about twelve

The inside of the crown of a hat, lined with cork, of about a cinater of an inch thick, and envered with white paper, will be found rery convenient, when collecting boxes are not at hand. 
by eighteen inches long, and four inches deep; and lined with cork at the top and bottom, and made to fasten close. Camphor must always be secured in the boxes to keep out mites, \&c.

A Pocket Larve Box. (plate, fig. 16.) This is necessary for the safe conveyance of caterpillars, and is merely a chip box, lined with white paper, having a square piece cut out of the lid, which should be covered with wire gauze, or coarse canvass, for the admission of air. One end should have a hole and a cork fitter! to it, to put the caterpillars in. But a box made of tin, perforated with minute holes, and having a hole at one end, as above, is by far the best, as the food does not wither so soon as in chip boxes. Some of the plant on which the caterpillars are found, must be placed with them.

Breeding Cages. (plate, fig. 1\%) These are for the purpose of rearing butterflies and moths, from caterpillars. The general form is square, having the sides covered with brass wire gauze 


\section{1}

or course canvass; the door should be as large as possible. In this may be set a small garden pot (placed in a pan), and filled with vegetable mould and rubbish, which may be got from rotten trees, having a wide-mouthed phial of water placed in a tin tube, and sunk into the mould to receive the food. An old snuff canister will answer very well, and the phial may be removed when it is necessary to change the water, without disturbing the earth, which may be kept moist, by occasionally pouring a little water into the pan. The mould is for those caterpillars which change to the chrysalis state under ground, Common garden pots, three parts filled with mould, and having three sticks placed at equal distances, to support a piece of gauze, and tied round, make very good breeding. cages. The mould should be four or five inches deep. But if it be the wish of the collector to ascertain precisely the moth that proceeds from each caterpillar, an excellent cage invented by my friend Mr. Stephens, will answer the purpose to a great extent; a figure of which, by his kindness, will be found in the plate, fig. 


\section{2}

. . The following description of it is in his own words. "The length of the box is twenty inches; height, twelve; and breadth, six; and it is divided into five compartments. Its lower half is constructed entirely of wood, and the upper of coarse gauze, stretched upon wooden or wire frames; each compartment has a separate door, and is moreover furnished with a phial in the centre for the purpose of containing water, in which the food is kept fresh; and is halif filled with a mixture of fine earth and the dust from the inside of rotten trees; the latter article being added for the purpose of rendering the former less birding upon the pupce, as well as highly important for the use of such larve as construct their cocoons of rotten wood. The chief advantages of a breeding cage of the above construction are, the occupation of less room than five separate cages, and a diminution of expense; both important considerations when any person is engaged extensirely in rearing insects. Whatever be the cunstruction of the box it is highly necessary that the larva be constanily suppled with fresh food, and that the 


\section{3}

earth at the bottom should be kept damp. To accomplish the latter object, I keep a thick layer of moss upon the surface, which I take out occasionally (perhaps once a week in hot weather, and once a fortnight or three weeks in Winter) and saturate completely with water, and return it to its place: this keeps up a sufficient supply of moisture, without allowing the earth to become too wet, which is equally injurious to the pupe, with too much aridity. By numbering the cells, and keeping a register corresponding with the numbers, the history of any particular larea or brood may be traced."

It is very desirable (if it can be accomplished) to kecp each kind of calerpillar by itself, as some species will devour others, and even their own kind, if not well supplied with food. It shotild be borne in mind that they must never be disturbed while changing their shins. Care must be takien constantly to watch the breeding cages, that the insect may be secured as soon as it appears, and before it has had time to injure itself by attempting to escape. 


\section{4}

CAGES will also be necessary for rearing the grubs or maggots found in dung, rotten trees, \&c. The best thing for this purpose is a stone jar, of about a foot deep, and three or four inches in diameter, having a tin lid made to fit very close, and perforated with minute holes to let in the air. The grubs taken from old trees may be placed in a separate jar, and lightly covered with decayed wood ; and those taken from dung may also have a separate jar, and some dung placed over them. For the caterpillars which feed on the roots of grass, a separate jar may be half filled with mould, and the caterpillars covered with a turf of grass; the top of this jar should be tied down with coarse canvass. The two last mentioned jars should be sunk into the earth, so that the surface may be exposed to the different changes of weather, but should be secured against too much moisture. Another $\mathrm{j}^{\text {ar }}$ might be kept for the grubs and maggots found in dead animals or animal matter. The jars must be frequently examined to secure the perfect insects.

Some of the water bugs (Velia Rimulorum an! 


\section{5}

Hydrometra stagnorum) are occasionally found with wings, but this is of rare occurrence. And as their economy is very little known, the plan suggested by Mr. Curtis, "British Entomology," Vol. i. fo. 2, for confining different species " in a frame covered with coarse gauze, and floating them," would be an easy method of studying their natural history. The caddis worms might be bred in a frame, sunk to the bottom of a pond, allowing part of the frame to rise above the surface of the water*. 'The imperfect field bugs (Cimices) are easily reared in cages, taking care to supply them plentifully with the plant on which they are found.

Pill Boxes. The collector should carry out with him three or four dozen of pill boxes of different sizes. The smallest size for minute moths, flies, \&c. Only one insect should be placed in each box, as in opening the lid to put in a second, the first will generally either escape

* Mr. Donovan says, that "Swammerdam used to hatch the eggs, feed the laree, and preserve the pupa of aquatic insets, in a shallow dish, which he covered with white paper, occasionally moistened, and pierced in several parts for the admission of air." 


\section{6}

or be crushed. It is best to put the empty boxes in one pocket, and the filled ones in another. Before going out the collector must be careful that his boxes fit tight, and that the tops and bottoms are perfectly secure.

Quills, (plate, fig. 18.) having one end carefully stopped with cork and wax, and the other having a cork stopper, will be found extremely useful for keeping the minutest insects secure. The quill should be shaken every time a fresh insect is put in, to preserve those already captured.

Prxs. The size of the pin must correspond with that of the insect. The collector should never fail to take out a cushion filled with pins of various sizes. The best, and indeed the only maker in London, who has them of all sizes, and made expressly for the purpose, is Durnford, in Gracechurch Street. Needles must never be used for piercing insects, as they always rust.

Pocket Magnifier. (plate, fig. 19.) The 


\section{7}

best kind is that which contains three glasses in one case, the focal distance of which are half an inch, one inch, and two inches; these three glasses will, simple and combined, give seven distinct powers.

Setting Needle, (plate, figs. 20 and 21.) is simply a needle fastened into a thin piece of wood about three inches long; on the other end of which a camel's hair pencil may be secured. A pin curved towards the point, and fastened into a piece of wood, will also be found useful. These instruments are very useful for extending the wings and legs of insects; and the pencil for brushing off dirt, or extending the limbs of those which are minute.

Braces, (plate, figs. 2, 3, 5.) are merely triangular slips of card used for confining the wings, \&c. They should be made of stout hotpressed writing paper for delicate insects.

Setting Boards are pieces of board covered c 3 


\section{8}

with cork and papered. The cork should be close grained, about a quarter of an inch thick, and perfectly smooth. The best plan to dry insects, and at the same time to secure them from accidents, is to have a box about eighteen inches high, and nine square, having grooves in the sides for the setting boarus to slide in (plate fig. 22.) The boards must be at least two inches apart to prevent the pins from being disturbed. The door may be merely a frame covered with muslin to admit the air, and exclude the dust. At the bottom a drawer may be constructed, having four or six divisions, for holding pins of different sizes, braces, setting needles, \&c.

Cabinet. The present state of British entomo$\log y$, requires a cabinet of at least one hundred drawers. The best sized drawers are from fourteen to sixteen inches square, and about two inches deep. They must be glazed, to prevent the admission of dust or air ; the glass, (which should be flattened) must be fitted into a frame of the same size as the drawer, and rabbeted on the 


\section{9}

underside; and, parallel with the sides of the drawer, but a little lower, an inner side piece should be fixed, so as to form a cavity all round, of a proper width to closely receive the rabbet, and likewise to contain the camphor for preserving the insects from Acari, \&c., to emit the scent of which holes should be bored in the side pieces, and pin holes made in the paper which covers them. The cabinets are best in tiers of about twenty drawers each, shut in by a door; or double tiers may be made with folding doors : in this shape, they are rendered portable, and and others may be added as the collection increases, corresponding in size and uniformity. Cabinets should be made of well seasoned mahogany or wainscot; but deal is objectionable from its liability to warp and split. Strips of velvet should be glued round the edges of the doors, to make them shut close, and keep out dust, \&c.

The bottoms of the drawers must be lined with cork, of about one sixth of an inch in thickness, as free from cracks, holes, and knots as 


\section{0}

possible. The best kind of cork for the purpose, is that which is obtained from the wholesale cork cutters, under the name of cork soles, and which may be cut into strips, by a circular saw ; or, if they are fixed into a vice, they may be cut by a very fine saw ; taking particular care, however, not to use any grease. The edges of the strips should then be cut even, and glued, and the worst side glued on to a sheet of stout paper, laid on a piece of deal board, larger than the drawer intended to be corked; some strong pins or fine brads must be driven into each piece as it is glued down to keep it firm, until the glue is quite dry. The sheet of cork must first be smoothed down with a rasp, and then with a fine file, and finished with pumice stone; the sheet should then be cut to the proper size, and glued into the drawer, taking care to place a piece of board of the exact size of the inside of the drawer on the cork, and lay a weight upon it to keep the cork in its place. When perfectly dry, the cork and sides of the drawer should be covered with fine wove demy paper, not too thick, which should be well soaked with paste, 
and gently rubbed over with a clean cloth, until it is quite smooth.

The following mode of arrangment is that adopted by London entomologists, and is certainly the best calculated for displaying the affinities of a series of insects. Double pencil line are ruled to form columns, according to the width of the insects, which are to be placed between them. The larger species of Coleoptera, Orthoptera and Hemiptera are arranged side by side in pairs, and the smaller species in a greater number according to their size, having an open winged specimen below them. Hymenopteru, Trichoptera, Lepidoptera, and Diptera, are arranged singly, placing the males first: the sexes are always procured if possible. Of the butterflies four specimens are retained; a male and female showing the upper side of the wings, and one of each showing the underside. Of the moths, only the upper side is exhibited. Varieties are preserved as far as possible, as they are often of great use in determining species. The generic name is always stuck by a pin at the head of a 


\section{2}

genus, and the specific name immediately after each species.

Great care must be taken to keep insects from damp, for which purpose the cabinets should always be placed against the partition wall in a dry room. 


\section{3}

\section{INSTRUCTIONS FOR COLLECTING,}

$$
\S c .
$$

\section{WINTER.}

At this season of the year there appears so little to attract collectors, that few will venture out ; and others are deterred, from the idea that no insects are to be obtained. Many, however, are now to be found in certain situations, which at other seasons of the year are met with only by mere chance.

The collector, when going on an excursion, should always consider what his object is, and 


\section{4}

not incumber himself with more instruments than can be conveniently used.

One great employment for this season is searching moss. This should be collected from every possible situation in which it can be found, as roots and trunks of trees, banks in dry, sandy, and marshy places, margins of ponds, and even from the middle of meadows, commons, \&c. The trouble will be well repaid, as thousands of insects which make it their Winter abode, in Summer entirely desert it. The best times for collecting moss, are morning and evening; for in the middle of the day, many of the insects in mild weather, are either on the wing, or roving about. The moss may be put into bags, made of brown jean, or any other substance of close texture, and tied tight at the mouth, to prevent any insects making their escape. It should be minutely examined at home, by shaking a little at a time over a white dish or plate; a white soup plate is best, as from its depth, few insects can run up the sites. The insects, although in general 


\section{5}

small are not theless valuable, and should be carefully preserved, and put into quills as collected; they may be killed, by holding the quills in scalding water for a few seconds; and should then be pierced, or gummed upon wedges of stiff paper, as hereafter directed. If the labour of examining moss be too great for a person merely collecting for a friend, a quantity collected from various places would not be an unacceptable present, and might be sent, tied securely, in a large bag. Roots of grass, growing on banks, sides of ditches, ponds, roots of trees, \&c. should be pulled up and shaken into an- umbrella, a sheet of brown paper, or a pocket handkerchicf. 'This will be found a profitable mode of collecting, and may be pursued at most seasons of the year with success.

Many insects are found by pulling off the bark from decayed trees, with the digger. They will generally be found to adhere to the bark or body of the tree, and must be carefully touched, to prevent their falling. A wet finger will be found the best mode of taking the small ones. 


\section{6}

One hand should always be held under the bark, when separating it from the tree, to secure any insects that may fall. Grubs or maggots will also very often be found, particularly in the dead wood, and should always be very carefully taken out, and, if possible, a portion of the wood should be detached with them; a quantity of which should be put with them into the jar. Many chrysalides (pupa) will also be found in rotten wood. When a hole is discovered, the wood should be cut from the orifice, and the inhabitant carefully removed. For this purpose the pliers will be found very useful; taking great care, however, that the chrysalis be not squeezed.

Commons and marshes produce rare and interesting insects, peculiar to such situations; they will be found on plants which do not grow in cultivated ground; and many are fond of ground where the turf has been peeled off. In sand and gravel pits, under the loose sand and gravel, stones, turf, \&c. insects will be found. Throughout the year wherever stones, bricks, clods, 


\section{7}

rotten wood, decayed vegetables, and dead animals are met with, they should never be neglected to be turned over and examined. The dead moles which are often hung up in the fields should always be searched.

During the mild weather, trees of every kind, and underwood, should be dug round close to the roots, and for several inches from them, to the depth of a foot, particularly on the north side, for chrysalides and beetles. For this purpose a spade, gardener's trowel, or the digger may be used; but a better instrument is a potatoe fork, as the chrysalides dug up by this means are less liable to be injured. Stumps of felled trees, and the bark remaining below the surface of the earth, are the resort of many insects. The south side of banks, the bottoms of pales, walls, \&c. ought never to be neglected, as many insects may be dug from such situations. The chrysalides should be carcfully put into a box carried for the purpose, having damp earth at the bottom; care being taken to move them about as little as possible, as they are 


\section{8}

very likely to die if much disturbed; and for safe carriage the box must be filled up with moss, and carefully removed into a breeding cage or garden pot. If it is intended to send the chrysalides to a distance, they must be carefully packed in a box on layers of damp moss, and filled up with it to prevent their being shaken, and the box well secured with string. The Winter aigging for chrysalides, should not commence earlier than toward the latter end of January.

Water insects may be taken in ponds and ditches, in some situations in great abundance, if the weather be mild. As, however, they are to be found throughout the year, this occupation should not be followed at any time to the hindrance of digging, and collecting moss. Many collectors consider this season best for water insects, and seldom collect them at any other period; but undoubtedly the best time is from May to August. In fishing for them the water-net must be repeatedly drawn under the weeds, sometimes near the surface, at other: 


\section{9}

along the bottom and close round the sides, and the produce of the net carefully examined, and the insects secured. In the absence of a net the forceps may often be used, to entrap a water insect; and the weeds may sometimes be dragged to the shore with a hooked stick, when minute insects will be found attached. Some rare beetles are occasionally to be found adhering to the underside of stones in rivulets, and sometimes both in and upon the margins of brooks, ponds, \&c. under the mud.

Living animals, birds, and fish, should undergo a minute search at all seasons of the year; the insects found upon them are very interesting to the Entomologist, and distinct species will be discovered on almost every species of ani. mal and bird. The following method of taking them from birds, was kindly communicated to me by my friend Abraham Cooper, Esq. R.A. "Whenever I have killed a bird I wish to examine, I keep it by itself, and when it is quite cold, take it in my hand; the insects being then attracted by the warmth, leave the bird and crawl 


\section{0}

on the hand; from which I shake them into hot water." They may then be gummed on small wedges of siiff paper, in the manner hereafter directed. It would be very desirable, and assist very much in the investigation of the spee cies, if the insects taken from the different kinds of birds and animals, were labelled with the name of the bird or animal on which they were found.

The trunks of trees, pales, and walls (particularly under the projections), bushes in woods, shrubs, \&c. in gardens, should be carefully examined for many species of moths, which are not found at other seasons. These are easily caught by the forceps; or in a pill box, by placing the box and lid partly opened close to the insect, and shutting it in. The upper side of the wings of moths must on no account be touched with the fingers, but the underside of the thorax may be pressed sufficiently hard to kill them without injuring their plumage, before they are pierced. Small moths, \&c. had better be killed by sulphur, as hereafter directed, 


\section{1}

When examining trunks of trees and projections of pales and walls, chrysalides will occasionally be found attached; these must be removed with great care, and placed in an open box in a dry breeding cage, and left uncovered.

The Winter moths, although numerous, are generally rare in cabinets, which is to be attributed to the little search that is made for them. An assiduous collector would, there is no doubt, make some new and interesting discoveries at this season of the year.

The dung of horses, cows, deer, and sheep, is very productive of beetles, and should be searched throughout the year, and the grubs or maggots, which inhabit dung, carefully removed into a jar kept for the purpose. The grub of the bot-fly (Gasterophilus Equi) will, with others, be occasionally found in horse dung; and many beetles, fies, \&c. may be reared by this plan, as well at this, as at other seasons of the year. 


\section{2}

The white-thorn and other shrubs and trees, should be searched for the cocoons of different species of the large saw-fies, (Cimbicida) to which they will be found attached. 


\section{3i3}

\section{SPRING.}

Nature is now beginning to assume he, "lovely livery of green," and insects, whicl began to hybernate in the mild days of Septem. ber and October, are often found alert in the colder temperature of March.

Those who, from the nature of the weather, or other circumstances, have neglected to collect during the Winter season, may, during the month of March, follow the above instructions with considerable success. Moss may yet be collected in cold mornings and evenings, and digging round the roots of trees, underwood, pales and walls, banks of ponds, and fishing, may be continued. At this season, the dung beetles will be found very numerous, even in the roads. 


\section{4}

Searching on pales, walls, and trunks of trees for moths, should be strictly attended to.

As the "juicy groves put forth their buds," fresh insects continually appear. Beating, which will be one of the chief employments until September, may be commenced even in March; and at the beginning of April, caterpillars will be found. The branches of every kind of tree and shrub, and every plant and weed, should be beat into the clap net, or umbrella, which must be quickly pushed under the branches or weeds intended to be beaten, or the insects will fall to the ground. The sunny sides of the skirts of woods, lanes, helges, banks and roads, are the most productive places for beating. After several smart strokes with a beating stick, which will be necessary to dislodge many of the caterpillars, the produce may be examined, and the insects secured. The best time for obtaining caterpillars is very early in the morning, and late in the evening, as the greater part feed only during the night, and conceal themselves by day. 


\section{5}

It may be necessary to state, that it is by far the most preferable mode to collect the caterpillars and rear them, as the perfect insects which are caught on the wing are seldom found in a fine state. By rearing the caterpillars with ordinary care, and watching the appearance of the perfect insect, fine specimens may be obtained. It is, however, by no means intended to dissuade the collector from capturing them under any circumstances, for many species are only to be obtained in their winged state; their caterpillars being unknown. 'The middle and latter end of May, is the harvest to the collector of spring caterpillars; or, if the season be backward, from the beginning to the middle of June ; and every exertion should be made to obtain as many of each sort as can be conveniently supplied with food. These must be very carefully handled, and deposited in the box carried for the purpose, taking care to put into it some leares of the different plants on which they were found, and not forgetting to carry home a good supply. When taken home, they should be immediately placed in the brecding cage, and when it is necessiry to re- 


\section{6}

move them, to give them fresh food, care must be taken to examine the leaves that none be thrown away.

The butterfies are all day fliers, and many species are to be taken on the wing, at this season. A simple method will often bring them down even in their most rapid flight, and has been successfully employed in taking the Purple Emperior butterfly, (Apatura Iris,) namely, to throw up a stone or piece of tile before them, which they will very often fly down with, and alight on the ground, and are then easily captured.Some species will visit a single blossom, although disturbed half a dozen times; and thus, by watching their haunts*, may be taken with much less fatigue than running after them. But at an early hour in the morning, before the sun is very powerful, and about sun set, many will

* It shonld be remarked, that many insects are not only local, but have their peculiar haunts : some species being confined to one certain spot, and are not to be found in any other part of the same wood. When, therefore, the haunt of an insect is discorered, specimens may be taken on the same spot for many years in succession. 


\section{7}

be found on the flowers at the skirts of woods, and in marshes. A warm damp air, which often follows rain, is preferred by many species, when they will be found flying near the ground; and in hot and dry weather, they will occasionally settle on the mud in ditches. It should be remarked, that cool and windy days are very unfavourable for collecting them.- "The garden white butterfly, (Pontia Brassicce) is," says Harris, "as good a token for fine weather as may be ; when these flies are out in a morning, it selilom or ever happens but a fine day ensues." But the best guide to collectors, as to the flight of insects, is that of martens and swallows :for, as they live entirely on insccts, and accommodate their flight accordingly, it follows, therefore, that if they fly high, insects will be found very strong on the wing, but if the birds fly low, insects may be beaten out of the branches, or caught by the clap; net. Insects are usually abundant on the wing on the ayproach of a tempest or miny weather, maticularly :owards evening. 


\section{8}

Fine evenings, from March to October, (and indeed nearly throughout the year,) should be devoted to mothing.

"6 "Tis on some evening, sunny, grateful, mild, When nought but balm is breathing through the woods, With yellow lustre bright, that the new tribes Visit the spacious heavens, and look abroad On Nature's common, far as they can see, Or wing their range and pasture."

Although some species of moths fly by day, or in the afternoon, yet by far the greater number begin to fly towards sun set, and continue to fly to a very late hour. Indeed, it is most probable that many fly all night, as some species have been taken so late as twelve o'clock, and others, at the very earliest dawn :

"__before the powerful king of day, Rejoices in the East."

When the air is very serene, the skirts of woods, marshes, banks of rivers, and meadows, near hedges, will be found the best situations; but if windy, lanes in woods, and sheltered 


\section{9}

places; " twilight groves" and lanes are at all times excellent places, and a western aspect the best. Moonlight nights are rather unfavourable for mothing. On dark nights, a good plan for a single person to pursue, is to have a small "bull's eye" lanthorn, with a lamp burner, fastened to his hat by means of straps. If two persons are in company, one might carry a common lanthorn on a stick, elerated as high as the head, the other following with the clap net. The light will be found to attract insects; and, it is obvious, render it easy for them to be secured.

As many beetles, \&c.are only abroad in the evening and night, particularly after a warm shower of rain, numbers may be found about gardens, paths, roads, sand and gravel pits, \&c. by means of a lanthorn. Many species of beetles, chiefly (Carabida), may be found under clods of earth in ploughed fields at this season.

The field cricliet, (Acheta Campestris,) "makes its appearance about the 10th of March." It is extremely local, and generally gregarious, 


\section{0}

and may be taken by the mode pointed out by Mr. White, in his "Natural History of Selbourne" *. He states, that he found them inhabiting a "furze close, consisting of a rocky dry soil, and inclining to the afternoon sun." They make holes in the ground, generally terminating under a stone, and the only method by which he conil obtain them, was to insinuate a pliant stalk of grass into their caverns, and by probing their windings to the bottom, force out the inhabitants.

To mention the scveral trees, shrubs, and plants, on which insects are to be found, would he to give a catalogue of every tree and plant in the country. Although they should all be examiner, yet a few of the most productive may be pointed out. The oak harbours more cateryillars than any other tree; some very fine insects are also obtained by beating, and in its decayed wood are found some of our rarest beetles. The poplar and lime are both very productive; as are also the elm, willow and sallow, and the de- 


\section{1}

cayed bark and rotten wood, particularly of the elm, afford shelter to immense numbers of destructive beetles. The black thorn, while in blossom, should be carefully beat. But it is "where the white thorn whitens with lavish fragrance," to whose blossoms numerous species resort, that the collector will discover his greatest source of profit. Before beating this, or any other flowering shrub, a cursory glance will often detect an insect feeding on the blossom which may at once be secured with the forceps. But with respect to flowers in general, I beg once for all earnestly to recommend, that the " charming offspring of Flora" be carefully preserved, so long as they remain in blossom, as they furnish considerable employment and profit to the collector. They should be constantly watched, as beetles, bees, and other flying insects, are continually in search of "every opening" flower," and many hundreds will visit a single blossom in a day. The gooseberry and currant blossoms are continually visited by rarious kinds of bees. Sallow, as soon as it is in bloom, is a constant harbour formany bees and other insects, 
and will well repay the labours of watching. The sallow, in woods of about two or threeyears growth, bears fine bloom, and the insects are easily taken from it. Flowers in woods, marshes, meadows, and gardens, should be constantly searched, and many insects will be taken from them at this season, for a short time only which do not afterwards make their appearance. Clover, while in blossom attracts many insects, particularly moths in the evening. Gardens, where

"_- their delicious task, the fervent bees, In swarming millions tend,"

will be found continual sources of employment and profit, from April to September. From the trees, shrubs, and flowers, many insects may be taken; from the regetables, fine caterpillars; and from old walls and pales, bees, moths, s.c. Sand and gravel banks, in fine sunny weather, will be found very prolific in bees, and other four winged insects, and as they are extremely numerous, and new species are occasionally being discovered, every specinien possible should be 
taken. In these situations they will be found extremely active in their movements, and it will require considerable dexterity to catch them. The forceps is the only instrument that can be of service close to the banks, but the clap net will be useful for stragglers.

Some species of bees are subject to the attack of a most singular parasitic insect, (Stylops Melitta, plate, fig. 4.) which, from its rarity, and the singularity of its history, is a most interesting and desimble insect; the first bee it was found on was the Melittce nigrocenea of Kirby, (Andrenu of authors, plate, fig. 5.) but it has since been discorered on several other species *. 'The grub of it, (like the Ichneumonide larve in caterpillars) actually exists in the internal parts of the bee; and, when ready to assume its perfect state, works its way out between the dorsal segments of the abdomen; (plate, fig. 5. a. a.)

* This insect was first taken by A. H. Haworth, Esq. F.L.S., flying in his garden at Chelsea; and the Rer. William Kirby, F.L.S., afterwards found it on the above mentioned bee. For a rery full and inferesting accomnt and fignres of the disections of this cingular and inter- 


\section{4}

out of which it may sometimes be discovered obtruding its black head, "like an imp of darkness just emerging from the infernal regions." The most likely method of obtaining this insect, and probably other species, is to collect as many of the bees as possible, by means of the forceps, taking care not to hurt them, and put a few together, under a tumbler, supply them with a little honey and sugar, and allow them air; or, a better plan, to any one interested in the subject, would be to construct a small square cage, having the sides covered with wire gauze, and in ardditior:'io honey and sugar, stalks of sallow and fresh flowers, might be put into a wide mouthed bottle of water and placed in the cage, and the stalks changed every night. In speaking above of collecting all the bees for this purpose, I do not mean the honey bee, (Apis Mellifica,) nor the humble bees (Bombi); it is, however, not impossible, that they may be subject to the attack of a similar parasite.

esting insect, Vide Kirby's " Monographia $\Lambda$ pum Anglix," Vol, ii. p. 110, and plate 14, No. 2. Fig. 1. \&c. 


\section{5}

\section{SUMMER.}

Although an industrious collector, by strictly following the foregoing instructions for Winter and Spring, must have collected many species of insects, yet his grand harvest will be at this season; for many make their appearance only in the months of June and July. It may be necessary here to state, that with the exception of the employment to be found on sunny banks, and in sand, and gravel pits, the hottest hours of the day are not the most favourable for collecting. For insects in general are so very strong on the wing, and fly so high, that it is impossible to catch them; while others secrete themselves to avoid the heat. For bcating, therefore, the best time decidedly is early in the morning and late in the afternoon; and on dull days, which should be appropriated to this purpose. 
The umbelliferous plants, (wild parsnip, carrot, $\& c$.) in woods and hedges, produce the greatest abundance of insects. The blossoms of the elderberry should be closely watched so long as they last, at all times of the day ; but particularly at noon in the hottest weather of June and July. It should be observed that the best times for collecting from flowers is when the sun shines; although even in dull weather many will be found : and the same flowers which in the day attract various kinds of insects, are at night visited by moths, \&c. On dull days, and about sunset in fine weather, hedges and bushes, near ponds, should be searched for the various dragonfies (Libellulida), whichwill be found resting on the branches, and may be taken with the fingers; but when on the wing, they are extremely rapid in flight, and difficult to take.

Pine and fir trees should at all times be searched, both by beating the branches, pulling off the bark, and digging into the decayed wood; but at no season more than in the month of 


\section{7}

June, at which time some of our rarest and mosi beautiful insects are taken from them.

Trees, faggots, hurdles, \&c. and dead fences in woods should always be examined. Indeed, to point out the proper places for collecting, and the different methods, during this season, would be to repeat almost all that has been said under the head of Spring, and to mention every flower, bush, briar and tree, so numerous are the habitats; they may, however, be summed up by saying-search every where.

It has been already hinted, that this is considered the best season for collecting water insects, not only that they are to be found in greater abun. dance, but also that they may be collected with much less inconvenience than in the Winter months. But the collector must not be discouraged if he should search several ponds and not find a single insect; for it often happens that one pond, nay, even one side of a pond, will absolutely swarm with beetles, while several others in the neighbourhood, and even the 


\section{8}

other side of the same pond, may not produce a single individual; and as they fly by night, a pond which one day will be alive with them, will, perhaps, the next be quite deserted. Ponds on commons with gravelly bottoms, seem to produce the greatest number and variety of water insects.

From the time that the thistles begin to bloom, they should be constantly examined, for different species of humble bees (Bombi) will be found on them, in company with many other insects.

In August and September, the grasshoppers. (Gyrillida, \&c.) will be found abundant in meadows and marshes, and should not be neglected on account of similarity of appearance. About the same time the field bugs (Cimices) may be beat out of hedges, nettles, grass, \&c.

The Summer chrysalides may be dug for toward the latter end of June, and the beginning of July; in the latter month the greatest num- 
ber of moths make their appearance. Some little allowance must always be made for the time of appearance of insects in early and late seasons.

During the Summer the galls which are found on the leaves of the oak, willow, and other trees, and also the oak apples should be from time to time collected, for the purpose of getting the different species of Cynips and Eulophus (gall-flies), \&c. Branches of the trees having the galls on the leaves, should be gathered, and the stems put into a phial of water in a breeding cage, and kept until the perfect insects come forth. 


\section{0}

\section{A UTUMN.}

There is little to be done at this period, be* yond what has been pointed out for the Winter; to the instructions for which (as they very nearly suit the present season), I must beg leave to refer the collector. There is one remark, however, which should not be omitted, namely, collecting clirysalides by digging; the chance of breeding which will be much diminished by collecting them at an early period. But the chrysalides of the death's head moth (Acherontia Atropos) and many others, may be taken when potatoes are liug up. Persons who are thus employed should be directed to carry a box having a layer of damp moss at the bottom, and deposit the chrysalides as taken; they should be very careful not to disturb them more than can possibly be aroided. The reath's head moth ap- 


\section{1}

pears in October and November. The last brood of caterpillars will be found about the middle of September, some of which live till the Spring, and are very difficult to rear; but the greater part go into the chrysalis state before the approach of Winter.

Woods will still be found to produce many species of moths (particularly Tortrices and Tinea) by beating the underwood and hedges. Some species of gnats (Culex) and crane-fies (Tipula) peculiar to the season, may be found about ponds, and windows in houses.

The bollow stems of currant bushes, burdock, common dock, and various other pithy plants should be examined as well at this as at other seasons for chrysalides, as many caterpillars are internal feeders. Beetles also will often be found secreted in the hollow stems of decayed plants. The grubs found in apples, pears, and nuts, may be reared with care; they should be put into a cage having damp earth at the bottom. 


\section{2}

"Ivy is the last Hower that supports the Hymenopterous and Dipterous insects. On sunny days quite on to November they swarm on trees covered with this plant; and when they disappear, probably retire under the shelter of its leaves, concealing themselves between its fibres and the tree which it entwines *."

It is necessary again to remind the collector that many species of beetles found in dung and elsewhere, and, indeed, of insects in general, bear a very great similarity to each other; and to the eye of the inexperienced, may be considered as belonging to the same species, yet very many will be found on examination totally distinct from each other. To those, therefore, who wish to gratify their friends, by collecting for them, as well as those who have not had much experience in collecting for themselves, it is strongly recommended never to attempt to decide on species in the fields, but to collect all that are found; as otherwise from the above reasons, it is evident that they will preclude the probability of capturing new species whose dis-

* WHITE. 


\section{3}

tinction is trifling, as well as lose many others, the distinction of which can only be perceived by a practised eye, assisted by a lens. Nor should the Tyro while collecting, make a selection of species, nor consider the most beautiful as alone valuable, for the most insignificant insect in appearance, may, perhaps, prove the very key stone of a natural system !

From the circumstance too, that many insects are only abundant at distant and uncertain periods, varying from three to thirty years, or more, it is advisable for the collector, however common an insect may be,to take as many as possible at once, and not to run the risk of losing the species, by neglecting to take them at the proper time. Young collectors are also advised, when they are so fortunate as to meet with rare, or local insects in abundance, not to fail availing themselves of the opportunity to take more than they may require, in order not only to oblige their friends by the gift of specimens which they may not possess, but also to exchange their duplicates for other species which may 


\section{4}

be desiderata to themselves; by which means both parties are obliged and enriched by the labours of each other. To those who collect for their friends, it is suggested, that they should send them as many different sorts, and as many of a sort as possible. And it may not be useless to state, that those who oblige their friends, whose only object is to collect the indigenous insects of Britain, should never, on any account, send them foreign species, nor any that are doubtful, by being imported with merchandize, timber, plants, seeds, or otherwise, without separating, and labelling them, accordingly.

The entomologist would be gratified by having the date, habitat, locality, or any other particulars respecting captured insects: it would make the labour of the collector doubly valuable. The young student will of course keep a regular journal of the times of appearance, habitat, locality, food, \&c. \&c. of the insects which he captures. 


\section{5}

\section{LOCAL HABITATS.}

Is addition to the instructions already given, under the different seasons, a few local habitats may be pointed out. For, althuugh there is no situation which does not harbour peculiar insects, yet some are much more prolific than others, and may lie constantly resorted to with success.

Sayn, Gravin, Aan Chank pits. These places will furnish daily employment ; for insects are either attracted by the warmth or colour of the soil, or fall into the pits by accident; while others resort to such situations in search of their prey. Various kinds of beetles, bees, and other four winged insects, will be found about the banks. It is not enough, however, to scarch the mere surfice; stones, loose gravel, simel 


\section{6}

rubbish, and dung, must be turned over, and the banks scraped down with the digger. The banks of pits and ponds should be trod or dug down, and the loose earth examined; if the earth and tufts of grass be thrown into the water, the insects will be easily discovered on the surface. On the approach of Winter, many insects choose these places for their torpid abode; and in Summer, in the middle of the day, to escape the heat. Another method is, to stamp with the feet, for a few minutes, by the sides of ponds, and ditches, and in boggy ground, when beetles will often make their appearance, particularly in Summer. Many insects may also be taken in the Spring and Summer, by examining the roots of grass, while resting from more laborious exertion. It may be stated, that light and sandy soils furnish the most, and clay the fewest insects.

Stagiant Ponds, running streams, and their banks, have each their peculiar insects. 


\section{7}

" Where the pool

Stands mantled o'er with green invisible, Amid the floating verdure millions stray."

By examining the surface of ponds, many insects will be found, which fall in by accident.

Sandy Shores of the Sea, and Rivers. These situations produce peculiar and valuable insects. Search should be made under stones, rotten wood, dung, dead animals, weeds, and rejectamenta, at all seasons. The bottoms, sides, and fissures of perpendicular rocks should be constantly searched, also salt marshes and brackish waters; and trees, shrubs, and plants, near these situations should be well beaten and cxamined.

Forests axd Woods. Ail ground which has never been broken up, or cultivated, or which has lain waste for a number of years, contain the greatest number and varicty of insects, heaths excepted; which, though they have their rarities, are not very fertile habitats. These 


\section{$5 \mathrm{~S}$}

situations are generally little known, and therefore form a wide field for discovery. The New Forest, in Hants; Epping Forest, in Essex; Ashdown Forest, in Sussex; and Windsor Forest, in Berks; Combe Wood, in Surry; and Darent Wood, in Kent; are nearest to the metropolis; and the interesting species (peculiar to these places) which have been found, give earnest of the rarities which they still contain. The decayed trees, and water of these districts harbour rare insects; and to the collector, the only direction which can be griven, is to leave not a single place unsearched.

Marshes. The flowers of buttercups, and the rushes, flags, and flowers in ditches should be carefully examined; also ozier beds, and willows, which often abound in marshes. The morasses of Lincoln, Bedford, and Cambridgeshires; and Whittlesea Mere, in Huntingdonshire, produce some insects which are exceed ingly rare in other places.

Mouxtsins, \&c. The mountains, and indeed 
every part of Ireland, Scotland and Wales, are nearly new ground to the foot of the collector; they produce at every step insects new to our Fauna. To the enterprizing; a visit to these places would be well rewarded.

Fuoods. The rubbish left by occasional floods in the Spring and Summer, should be collected as soon as the waters begin to subside, in large bags, and tied tight at the mouth, and when brought home they should be immersed in scalding water. The bags should be left to dry, and the rubbish examined at leisure, by shaking a little at a time over a sheet of white paper. By this plan, myriarls of insects may be obtained.

Mesmoons axi) Toadstoors. (Fingi and Boleli.) These are found on the ground in meadows, commons, and parks; and also on trees. They occasionally contain rare beelles. A good plan, where a quantity is founc!, is to put it into an open jar to attract insects, or lay it in a lump under a herge; and when it begins to rot, many 


\section{0}

insects will be found in it. The grubs, may be placed in a breeding jar by themselves, with plenty of food, and should be constantly visited. Decayed vegetables and fruit should be well examined.

Windows, \&c. harbours many insects, and should always be examined; a collection of gnats, (Culices) might be made from these situations alone. Spider's webs, both in and out of doors, occasionally entangle rare insects.

Granaries, \&c. The sweepings of granaries, corn bins, \&c., particularly if corn has lain some time in them, will repay the trouble of examination. The caterpillars of several species of small moths will be found in the rubbish, particularly Tinea granella. Tan yards, corn mills, and bakehouses, will also reward a search.

Hop Gardens. The hop plant is the resort of many peculiar caterpillars and beetles. But as it is too valuable to be beaten as before directed, many insects may be letected lurking un- 
der the leaves, while the plants are growing. But when the hops are being picked, those who live in the neighbourhood, have a fine opportunity of getting many insects.

Sheep Fouds, should at all times be searched for insects which torment the sheep; and when they are sheared, their parasites may be taken. Also about cattle, the bot fies, (OEstrus) \&c. may be taken. White horses are most tormented with the forest fly, (Hiprobossa). 


\section{2}

\section{PECULIAR METHODS}

OF

\section{COLLECTING INSECTS.}

The following peculiar methods of entrapping insects, will be found very useful for obtaining many species, which are otherwise rarely taken. Several of these methods the author has found very successful.

Laying Batts. An excellent method, and by which a great number of insects may be obtained, is by laying wide-mouthed bottles, baited with raw meat, tripe, \&c. in sunny banks, concealed among the long grass. The bottles should be buried up to the neek, in an 


\section{3}

upright position, and as soon as the contents begin to decompose, many insects will be found. They may be visited every morning, and the insects shook out upon a sheet of brown paper, carried for the purpose. Traps similar in construction to those used in houses for catching cock-roaches, (Blatta Orientalis) and baited as recommended for the bottles, might also be employed. The aperture should be so small as not to admit mice, which are destructive to insects. Old cellars, subterraneous passages, barns, stables, damp pits, \&c. also contain various insects, which might be taken by this means. Another method, also very successful during the Spring and Summer, is laying bones (particularly marrow bones), with a little meat left on them, horns of sheep, \&c. about sind and gravel pits, woods and gardens.

Dung of Horses, \&c. An excellent method for those who hare the opportunity, for taking beetles from the llung of various animals, is pointed out by Messrs. Kirby and spence *,

* Introduction to Entomology, Vol, iv. p. 523. 


\section{1}

namely, to immerse the dung in water, when the insects will be found swimming on the top: many may be collected this way, which from their quick morements escape observation, in the ordinary mode of collecting. Pieces of board, laid on dung heaps or cucumber beds, in the months of June and July, will attract small beetles, (Pselaphide) which will be found to adhere to the underside.

Old Trees, dead fences, and felled timber, should always be carefully examined. From the little round holes many beetles and bees may often be obtained, by inserting a stem of grass, or straw, and probing the holes to the bottom. Tobacco smoke infused into the holes, will also quickly bring them out. The forceps must always be kept close to the hole to catch the insect as soon as it appears. The holes in banks might also be probed with success. Hedge-stakes, perforated with holes, should be carefully split, for they harbour small beetles and other insects. Timber in yards should be 


\section{5}

well searched, and the holes probed or smoked; and the insects found on or near foreign timber, kept separate and labelled.

Beating Trees. Beating into a clap net or umbrella has already been recommended, but a far more profitable mode may be adopted, by two persons carrying a large sheet, while a third, with a pole twenty or thirty feet long, beats the highest branches of trees. Not only rare beetles and other insects are thus obtained, but also caterpillars, which only feed on the highest branches. From oaks the beautiful caterpillar of the purple emperor butterfly (Apatura Iris) may be beaten. A sheet laid on the ground in a garden or wood in a hot Summer's day will attract many insects. As sweets will attract them within doors, there is little doubt but they might be employed to advantage without. Sheets of white paper smeared with honey water, beer, and sugar, or sugar sprinkled over them would answer the purpose.

'Taking Caterpiluars. A method of collect- 


\section{6}

ing caterpillars I here transcribe from the "New Times," of the 24th of August, 1820 ; premising, that it might be tried in potatoe grounds in September, for taking the caterpillar of the death's head moth, (Acherontia Atropos) which, as well as many others, only feed by night, and conceal themselves during the day. "A gardener at Glasgow has a mode of destroying caterpillars, which he discovered by accident. A piece of woollen rag had been blown by the wind into a currant bush, and when taken out was found covered with those leaf-destroying insects, He immediately placed pieces of woollen cloth in every bush in his garden, and found the next day that the caterpillars had universally taken to them for shelter. In this way he destroys many theusands every morning." Many caterpillars may also be found at night by searching the various plants in gardens, woods, and hedges, by means of a lanthorn.

ATtactivg Motrs, \&e. The following method has becu very successfully cmployed on 


\section{7}

fine evenings, during the Summer. Having a table placed near an open window facing a garden, or in a summer-house with a lanthorn or large lamp, the flame being secured by a glass, the light will attract moths and other nocturnal insects, and numbers may be taken with the forceps. Barbut, Harris and others, mention a practice which has long been successfully adopted by London collectors for attracting the males of the fox, and grass egger miths, (Lasiocampa Rubi, and Quercus.) When they have bred or taken a female of either of those species, they put her alive while a virgin, into a box with a gauze lid, and take her to a wood, and, in favourable weather, she never fails to attract a number of males, which are easily taken. There is little doubt but that many other species of insects might be attracted, if exposed in a similar manner. 


\section{INSTRUCTIONS}

FOR

\section{KILLING AND PRESERVING}

\section{INSECTS.}

Before entering on the subject of the best method of killing and preserving insects, a word or two may not be out of place on the subject of cruelty, with which the collector is so often charged. This, to say the least of it, is inconsiderate, for the very person who would feel shocked at the idea of killing a beetle, would the next moment eat a living oyster, or partake of eels, stimned, and very probably fried alive, without a symptom of remorse : so much for consistency! But, as the excellent 
authors of the "Introduction to Eniomology," have so ably rebutted the charge of cruelty, in the second letter of the first rolume of that admirable work, it will only be necessary to refer the reader for answers to the objections which have been raised. As the author is an advocate for putting insects to the most speedy death, he begs to suggest the means by which it may most easily be effected.

Beetees, and Field Bugs, of a black or dark colour only, may be put into a phial half filled with weak spirits of wine, (which is the least objectionable) by this means they are instantly killed; when taken home pour the contents of the bottle on a piece of muslin over a cup, and return the spirit for future use; then place the insects on blotting paper, to absorb the moisture. It is wished to impress upon the collector, that only dark coloured insects should be put into spirits; as the colours of bright species are very much injured, if not entirely destroyed by them. Beetles and fieldbugs are also instantly killed by being plunged 


\section{0}

into boiling water ; but this mode is objection able for bright coloured or hairy insects. When taken out of the water they must be laid on blotting paper. The most preferable method of killing beetles, \&c. is to place them in a tin box, or cannister, and then immerse it in boiling water, taking care that no water find its way into the inside; by this means the insects are not only quickly killed, but their colours are preserved, and the juices partly absorbed; which renders them much less liable to mold or grease.

With regard to the larger kinds of butterfies, moths, and dragon-fies, when taken, they should be sharply pressed with the finger and thumb on the underside of the thorax, hard enough to kill, but not to injure them; taking particula: care not to touch the upper side of the wings. A pin should then be passed through the upper side of the thorax in an upright position, (as shewn pl. fig. 3.). Those which are more tenacious of life, are instantly killed by dipping a pin in aqua fortis, and piercing the insect in the breast. Small moths, flies, \&c., are instantly 


\section{1}

Filled by the fumes of sulphur. If the insects are in pill boxes, elevate the lids on one side very slightly, place the buxes under a tumbler or bason, and put a lighted match underneath, taking care not to scorch the boxes. When the match is suffocated withdraw it, and let the boxes remain for a few minutes, when the insects will be found dead *.

The fiying insects (Neuroptera, Hymenoptera, Trichoptera, and Diptera,) may be killed by squeezing the thorax, or piercing them in the breast with a pin dipped in aqua fortis. Small insects in quills are immediately killed, by putting the quills into hot water, for a few seconds.

* The eggs of butterflies and moths, which are often laid in the collecting box, should be carefully preserved, and the young caterpillars, when hatched, supplied with food. If their proper food is not known they should be tried with the leares of various kinds of trees and plant: Specimens of rery rare insects hare been reared fiom egg; thus obtained. It is an astonishing fact, and shews the wonderful provision of nature for the preservation of her creatures, that it is almost impossible to liill a female of this and other tribes of insects before she has lain her eggrs. 


\section{2}

'This is preferable to holding' the quills over a candle, as the insects are sooner killed, and their juices are not dried so quickly as to prevent their legs, and antennæ from being displayed.

Having killed the insects, the next step is to preserve them. Beetles should be pierced by a pin of corresponding size, in a perfectly upright position, through the right wing case (Elytron) as shown (plate, fig. 1,) and never through the thorax. The legs and antenne should be displayed in a natural position on the setting-board, and kept so by means of pins, and braces, (as also shewn plate, fig. 1.) where they should remain until they are perfectly dry. Minute beelles and other insects, should be gummed* on small wedges of card or stiff paper, and the wedges stuck with a pin (plate, fig. 4 ani 6.) The grum should be thinly spread, with a camel's hair pencil, and the insect placed upon it, the legs \&c. being extended by means of a clean

* Commion gum water will not hold sufficiently strong, isinglass must be mixed with it in a suficient quimtity to make a strong jelly when cold. It may be warmed when used. 


\section{3}

pencil. Field bugs, butlerflies, moths, bees, and other winged insects, and also flies (Diptera) should be pierced as represented in the plate, fig. 2,3 , and 5 .

All the winged insects, should have their wings extended before they are stiff, by means of braces, as shewn in the plate, fig. 3 , and 5 , the wings being elevated with the setting needles; and the braces must remain several days on the insects, until their moisture is evaporated, and they are quite stiff. As the underside of the wings of the butterflies are not only very beautiful, but it being necessary to shew them to determine some of the species, those specimens whose upper wings are rubbed, should be selected for the purpose, and pierced with a pin in the centre of the underside of the thorax. A single brace for each wing will often be sufficient. In piercing insects, it should always be remembered, that the pin should exteacl at least a quarter of an inch through the insect. The wings and wing cases (Elytra) of beetles; \&c, may be extended in a similar manner, by piersing the insect in the centre between the two 


\section{4}

cases, and the elytra and wings extended, as shown plate fig. 2. To set insects well, requires considerable practice, and would perhaps be too great a tax upon the patience of those who collect for their friends. It is therefore needless to trouble them, as the entomologist can always relax the insects sent, and in most cases would prefer setting them himself. But they must be pierced as upright as possible. Small moths require very great care in piercing. After being killed by means of sulphur, they should be shaken out of the box into the palm of the hand, and the pin passed through the thorax, (without touching the insect with the fingers,) the head of the pin inclining very much over the head of the insect; by this means, when the pin is placed upright on the setting board, the moth will be in such a position, that it will be only necessary to elevate the wings slightly with the setting needle, and the insect will be completely set, without the aid of braces.

Insects which have been pierced, are very easily relaxed, by sticking them on a piece of 


\section{5}

cork, and letting the cork float in a bason half filled with water, taking care that no part of the insect touches the cork. If the bason be covered with a damp cloth, they will be the sooner relaxed. If the insects are not pierced with a pin they should be laid in the lid of a tin box, and placed on the floating cork; beetles, \&c. may be placed on damp flannel in a plate and covered with a bason. Some insects require a very short time to relax, others several days; they may be set by means of braces and pins, in the same manner as recent specimens,

If by any accident a leg or any part of an insect be broken it should immediately be gummed on, and on no account whatever, should the vile practice of supplying limbs from another insect be adopted. Mouldy insects may be cleaned by means of a camel's hair pencil, dipped in spirits of wine ; but it should be very sparingly used for high coloured species.

The colours of the dragon flies (Libcllulida) and 
some grasshoppers, (Locustida, \&c.) will be entirely lost, and the body shrivel up; and the bodies of many large moths are also very liable to grease, unless they are stuffed. The underside of the body must be cut open by means of a fine pair of scissors, and the contents removed as carefully as possible, as soon as they are dead. The cavity should be nicely filled with a roll of white cotton or blotting paper, so as to give the insect its proper shape. The species of the blossom eating beetles (Melöe) with soft bodies, must undergo the same preparation. For old specimens of insects which turn greasy, French chalk scraped over them and then exposed to the heat of a fire will often remove it ; but the chalk must remain on for several days, and the process repeated until the grease is eradicated.

To preserve the eggs of butterfies or moths, the following method, practised by Swammerdam, (quoted by Mr. Donovan) will be found to answer the purpose. "Pierce the eggs with a fine needle, and press the juice through the 


\section{7}

aperture; then inflate them, until they regain their proper form, by means of a small glass tube, then fill them with oil of spike in which some resin is dissolved."

To Preserve Caterpillars. The animal must first be killed by immersion in spirits of wine, then empty the contents of the body by the gradual pressure of the finger and thumb, beginning at the head, and pressing on to the anus, at which part a small aperture should be previously made. When the skin is cleared as much as possible, introduce a piece of hay or slender straw into the anus, round which, and near to the extremity, pass loosely a fine thread; then blow through the tube, and when the skin is fully inflated, withdraw it, at the same time pulling the thread tight, and secure it by a knot. The caterpillar will now exhibit its proper shape and colours; to retain which, all that is necessary, is to hold it near the fire, until perfectly dry, which will be in a few minutes. Another method is, when the contents of the body are 


\section{8}

removed as above, to fill the skin with very fine dry sand; by this means the insect is brought to its natural shape; in a few hours the skin will dry, and the sand may be shaken out. C $\quad$ aterpillars, thus prepared, may be either pierced with a pin, or gummed on a strip of card. They may also be preserved, without any further preparation by merely suspending them from the cork in a phial filled with spirits of wine. The phial should be close stopped, and the cork dipped in wax. When caterpillars, either from their rarity or otherwise, cannot be preserved, a coloured drawing should always be made of them when in their last skin.

The shells of chrysalides have merely to be pierced through with a pin, or gummed on a piece of card when the insects have left them : or, if it be wished to kill a chrysalis, it may be done in a moment by dropping it into scalding water. Mr. Donovan says, that " if the chrysalides which have the appearance of gold, are 


\section{9}

put into spirits of wine, they will always retain that colour, but, if the insect within is killeci first, or, if the fly has quitted it, such appearance is entirely lost."

To Preserve Spiders. (Aranea, Lin.) This tribe of animals, which are exceedingly numerous, and present an infinite variety of form and beauty of marking, are generally neglected by the collector from the difficulty of preserving them, The following method is recommenderl by Mr. Donoran: " after the spider is killed by means of hot water, the entrails should be immediately extracted, then inflate them by means of a blow pipe, and cleanse the inside no more than is sufficient to prevent mouldiness for fear of injuring the colours; the abdomen may then be filled with sand." This will, in general, answer the purpose; but the following method, mentioned to me by J. H. Griesbach, Esq., is very successful. Pierce the spider through the thorax with a pin, and put it into a deal box, and hold it near the fire for a few minutes; when the insect will be found dead, the con- 


\section{0}

tents of the abdomen dried, and the form and colours preserved. It will require a little practice to determine the exact time it should remain; for if left too long, or the heat is too great, it will burst.

Insects must always be put away out of the reach of spiders, earwigs, \&c: which will destroy in one night the labour of many days collecting; and care must be taken to secure camphor in the boxes to keep out mites, \&c., which are very destructive to them.

Packing Insects. Great care must be taken in packing, or the labour of the collector will have been in vain. 'Those insects which are pierced, might be sent pinned firmly into a corked box kept for the purpose; but loose ones are best sent in tin boxes, filled up with bran or sand; taking particular care that the insects, as well as the bran or sand, are perfectly dry, and filling up the box to prevent breakage. Caterpillars should have a plentiful supply of leaves, as well for food on their journey, as also 


\section{S1}

to keep them from being shaken. Underground chrysalides should be sent in boxes covered with damp moss, while those which change above ground may be packed in dry moss, or cotton.

To remove the prejudice which is often felt against insects by persons unacquainted with them, and yet are willing to collect for their friends, they may be assured, that, with the exception of bees, hornets, and wasps, (which are easily secured by means of the corceps,) all the rest are perfectly harmless. 


\section{INSTRUCTIONS}

For COLLECTING AND PRESERVING

\section{CRUSTACEA AND SHELLS.}

As many Entomologists collect Crustacea and Shells, a few brief instructions for collecting and preserving these interesting objects, may not, perhaps, be unacceptable.

Crustacea, (familiar examples of which are, crabs, lobsters, shrimps, and woodlice,) are extremely numerous. Animals of this tribe are found in every possible situation on the seashore; in empty shells, under stones, rubbish, sea weed, little pools, or buried in the sand. 


\section{3}

Many species are also found in rivers, stagnant ponds, and ditches, and are often brought up in the net while fishing for insects. Many are found uponvarious kinds of fish; and others under the bark of decayed trees. After a storm, or gale of wind, as well as on the retiring of the tide, the beach should be well searched. Many, it is possible, make their appearance only in the evening and night. The fishermen and shrimp-catchers should be requested to preserve any which they may drag up; and the different fish brought to market should be examined. By this means rare and interesting species may be obtained. Many of these animals are extremely local, and the collector should be careful not to neglect the opportunity of taking a sufficient quantity, however plentiful they may appear; for it often happens that what is common with the collector, is unknown to the naturalist.

For collecting Crustacea, the smaller linds might be put into a wide mouthed bottle, half filled with water or spirits of wine. The larger 


\section{4}

crabs, \&c. should have their claws tied, to prevent their injuring each other, and might be put into a bag. Those found near the sea, may be killed by being put into cold fresh water, and should remain some hours to extract the salt. The fresh water species are easily killed by being plunged into spirits of wine.

They should be pierced with proper sized pins, and their legs, \&c. placed in a natural position. If intended to be sent to a distance, they may be stuck in a corked box, or wrapped in soft paper and packed in a box, on layers of cotton; taking particular care of their legs, \&c. which are very brittle when dry.

Sinelus. With regard to collecting shells, it is necessary to hint to those who reside at or visit the sea coast, that the best shells are those in which the animal is found alive; the empty shells are of little value, as the sun and tide destroy thcir beauty; still they are not to be rejected. 


\section{5}

Fishermen often drag them up in their nets, and should be requested to preserve any they may find. It also often happens that among the esculent shell-fish brought to market, otlier shells may be found. Gales of wind, and storms, often throw up live shells on the beach: collectors should search for them immediately on the ebbing of the tide. The coasts of Cornwall and Devonshire are the most productive in England.

Many fresh water species may be collected when fishing for insects; and an immense number of species of snails (Helix,) \&c., might be got together in the course of one year, while in search of insects. Those who are interested in the study of Conchology will, of course, keep the animals alive a few days, in order to observe their structure and habits. The collector should ever bear in mind, that none should be neglected from their apparent similarity.

When it is wished to kill the animal in the shell, it should be put into scalding water for a 


\section{6}

few scconds, and then plunged into cold water, which condenses the fish and renders it easier to be extracted. Crooked wires will, in general, be found useful, in perfectly extracting the contents of the shell.

The collector should be provided with a canvas bag, for the larger sorts, and a wide mouthed bottle or tin box for the smaller ones; also one or two oyster knives, for taking shells from the rocks, and a hammer and chisel for such as perforate rocks and stones. A landing net, with very small meshes, or the net used in fishing for insects, and a small spade will be necessary to dig for those which bury themselves in the sand. 


\section{LIST, \&c.}

THE following is a short list of Inscets, \&c., the greater part of which have been recently added to the British Fauna. Some are unique, and many of them very rare, and the greater part are desiderata to the London Cabinets. For the description of the insects, the student is again referred to Mr. Stephens's forthcoming work. The habitat, locality, and period of appearance have been inserted, so far as could be ascertained. The figures refer to the months in which they have been captured; and those printed in italics are referred, in Mr. Samouelle's calendar, to a different habitat or locality.

\section{N S E C T A.}

\section{COLEOP'TERA.}

Alpæus castaneus. Under stones, Devon, 5.

Apate muricata. Under bark, Epping Forest, 6.

Aphanisticus emarginatus. Moss, Coombe Wood, 4.

Aphodius bimacnlatus. Under dung, Windsor, 6 .

Peccari. Dung, Windsor, 6.

tessulatus. Dung, Old Ford, Mr, Beck, 4. Aspidiphorus orbiculatus. Hull? Mr. Spence. Atherophagus nigricornis. Flowers, Hertford, 6. Berosus obsoletus. Ditches, Whittlesea-mere, Mr. Chant, 5. Blemus discus. Windsor, and Hackney Marshes, 4. unifasciatus. Greenwich Road, 6.

Bolbocerus mobilicornis. Dung, Darent, Kent, 6 . Brachinus glabratus. Under stones, Dower, Mr.Stephens, 7. sclopeta. Under stones, Devon, Dr. Leach, 9. Buprestis ænea. Ebberley, Devon, 6. Byrrhus cinctus. Gravel pits, Hampstead Heath, 4. Callidium fennicum. Oaks, Hainhault Forest, 8. 
Callidium testaceum. 'Trees, Battersea, 6.

Carabus auratus. Under stones, Norfolk. convexus. Under stones, Salop, 4.

Cassida vittata. Flea-bane, Windsor, 7.

Chlænins melanoceras. Whittlesea-mere, 7 .

Cleonis albidus. Gravel pits, Suffolk, 7 .

glaucus. Cobham Heath, 6 .

Clerus alvearius. Dorking, Mr. Waterhouse, 6 .

Colymbetes Grapii. Norfolk, Mr. Curtis, and Whittlesea, 5.

Cucujus complanatus. Granaries and Corn-bins, 12.

Dendrophilus seminulum. Gravel pits, Coombe, 3. 6 .

Diaperis ænea. Fungi, Ripley, 7 .

Distomus Leachii, Devon, 6.

Donacia dentata. Aquatic plants, Salisbury, 7. potamogetonis. Aquatic plants, Salisbury, 7. semicuprea. Aquatic plants, Salisbury, 7.

Dromius meridionalis. Southeud, 4 . notatus. Southend, 4.

Elaphrus cupreus. Marshy places, Chelsea, 9.

Elater aulicus. Trees, Devon, Dr. Leach, 6.

bimaculatus. Underwood, Darent Wood, 5.

brunneus. Underwood, New Forest, 6.

Equiseti. Underwood, Birch Wood, Kent, 6.

fugax. Underwood, New Forest, 6 .

pubescens. Decayed Trees, Ncw Forest, 6.

sanguinicollis. Stumps of 'Trees, Copenhagen

Fields, 10.

serıaticornis. Underwood, Bristol, 6 .

testaceus. Underwood, Bristol, 6.

varius. Underwood, Windsor, 6 .

ustulatus. Underwood, New Forest, 6 .

Elicopis impressus. Rotten Elms, Hyde Park, 1. 2. 3.

Emus hirtus. Dead animals, New Forest, 7.

Eumolpus pygmæus. Willows, Swansea, 5.

Galleruca rustica. Aquatic plants, Whittlesea, 6.7.

Heterocerus lærigatus. Mud of Ponds, Copenhagen Fields, $6,9$.

Hister merdarius. Dung in Fields near London, 4.

Hylurgus sulcatus. Timber Yards, Southwark, 8.

Hypophlæus bicolor. Bark of Elm, Kensington, 2. 4.

Hypulus quercinus. Oak, Darent and Coombe, Mr. Stone, 6.

Lamprias rufipes. Underwood, New Forest, 6.

nigritarsis. Broom, Darent Wood, 6.

Lebia hæmorrhoidalis. 'Trees? Netley, 6. 
Leptura abdominalis. Flower's, Darent Wood, 6 .

4-fasciata. Umbell. flowers, Colney Hatch, 8.

præusta. Flowers, New Forest, 6.

scutellata. Decayed trees, New Forest, 6.

Malachius ruficollis. Plants, Whittlesea, 6.

Melandria canalienlata. New Forest, Mr. Bentley, 6.

Monochamus sartor. Ebberley, Deron, and Surrey, 6.

Nebria picicornis. Under stones? Salop and Devon, 5.

Nemosoma elongata. Darent, Mr. Stephens, 6.

Nitidula strigata. Under bark, Coombe, 3.

Nosodendron fasciculare. Devon, 5. setigerum. Devon, 5 .

Onthophagus medius. Dung, Battersea, 7.

Ophonus obscurus. Hackney Marshes, 4.

Orchesia fasciata. Boleti ? New Forest, 7.

Orobitis globosus. Gravel pits, Coombe, 6 .

Orsodacna humeralis. Oak and White thorn, Mr. Bainbridge, 5,6 .

Panagæus 4 pustulatus. Under stones, Hertford, 6 .

Patrobus rufipes. Under stones, Battersea Fields, 6. 9.

Plinthus caliginosus. Charlton, Coombe, and Highgate, 8.

Phaleria cornuta. Meal, 6.

Polistichus fasciolatus. Southend and Cley, Norfolk, 4.

Saperda carcharias. Trees, Dean Forest, 7.

Silpha nigrita. Fields, Yorkshire, 8.

Stenolophus raporariorum. Gravel pits, Wandsworth, 4,9. vespertinus. Banks of Pends, Copenhagen Fields, 6.

'Tenebrio ferruginea. Old bran, Bakehouses, 8.

Throscus obtusus. Oak, 9, Mr. Westwood, Moss, 10.

Tillus ambulans. Oaks, New Forest, 6.

Trachys nana. Underwood, Coombe, Mr. Stephens, 6.

Trachyscelis Aplodioides. Sandy places, Ncw Forest, 6.

Trichius variabilis. Trees, Windsor Forest, Mr. (rriesbach, 6 .

Xylita rufipes. Rotten trees, Windsor Forest, Mr. (iric:sbach, 7 .

\section{ORTHOPIERA.}

Acheta italica? Norfolls, Mr. Haworth, 6.

sylvestris. New Forest, 7.

Acrida verrucivora. Fields, Rochester and Dover, 7, 8.

Blattalapponica. 'l'rees, Albury, 6.

pallida. Trees, Devon, 6 . 
Blatta Panzeri. 'Trees, New Forest, 6. perspicillaris. Underwood, New Forest, 6.

NEUROPTERA.

Eshna Dalii. Whittlesea-mere, Mr. Dale, 6. Cordulia compressa. Near Ponds, Dorset, 7. Gomphus pulchellus. Dover, Mr. Stephens, 8.

\section{HYMENOPTERA.}

Amasis obscura. Lincolnshire, 5.

Chrysis fulgida. Gravel banks, Coombe and Epping, 6. 7. Peltastes necatorius. Plaistow Marshes, Mr. W. Beck, 8. Psen Equestris. Gravel banks, Coombe, 7. Rhopalum rufiventre. Gravel banks, Coombe, 7. Urocerus magus. 'Trees, near London, 6. juvencus. Pine trees, Bexley and Bessell's Green, 7, 8 .

\section{HEMIPTERA.}

Agramma læta. Moss, Coombe, Mr. Westivood, 10.

Alydus calcaratus. Broom, Coombe Wood, 7.

Orthonotus leucocephalus. Grassy banks, 7 .

Tetyra obliqua. Gardens, Islington, Mr. Cooper, 10.

\section{LEPIDOP'TRA.}

Acontia Solaris. Dover, 6.

Agrotis margaritosa. Hackney, 9, 10.

pyrophila. Southgate, 7 .

radiatus. Derby, Devon, 7 .

renigera. Scotland, 6 .

subgothica. Barnstaple, Mr. Raddon 8, subterranea. West Ham, 6.

Templi. Birmingham and Liverpool, 9.

Alcis sericearia. New Forest, 6.

Catocala promissa. Trees, Richmond Park, 6.

Cerura bicuspis. Darent Wood, 7.

Cliaradrina glareosa. Birch Wood, 9.

Cleora cinctaria. New Forest, 6 . teneraria. New Forest, 8. viduaria. New Forest, 6.

Colias chrysotheme. Norfolk, 9 .

Europome. Lewes and Brighton, 7 .

Euplocamus mediellus. Birch Wood, 9.

Geometra delunaria. Birch Wood, 6.

Glyphipteryx Schafferella. Plants, Stoke Newington, 8.

Graphiphora ravida. Heaths, Hants, 8. 
Hepialus carnus. Birmingham, 8.

Hipparchia Hero. Ashdown Forest, 6 .

Ligea. Isle of Arran, 8.

Mnemon. Cumberland, 6.

Lasiocampa Medicaginis. New Forest. 6.

Spartii. New Forest, 7.

Leiocampa dictæoides, Darent Wood, 7.

Lobophora viretata. Darent Wood, 6.

Lophopteryx cucullina. Birch Wood, 3.

Lucania impudens. IVhittlesea-mere, 7.

Macaria emutaria. New lorest, 6. strigilaria. Darent Wood, 6.

Miselia bimaculosa. Bristo!, 6 .

Notodonta torva. Dublin, 7 .

Ophiusa? anomala. Heaths, Hants, 8.

Papilio Podalirius. New Forest, Mr. Hawkins, 8.

Plusia aurifera. Dover, Mr. Lyon.

Psyche fusca. Hornsey wood, 6.

Ptilophora variegata. Birch Wood, 9.

Simyra musculosa. Whittlesea-mere, 6 .

Speranza sylvaria. Scotland, Mr. Dale. 7.

Tortrix turionana. 'Trees, Regent's Park, 8.

Valeria oleagina. 'T'rees, Richmond Park, 7,

Xylena conspicillaris. Birch Wood, 6. perspicillaris. Birch Wood, 6 . pulla. Woodside, near Epping, 6.

DIP'TERA.

Atherix Ibis. 'Trees, Darent River, Mr. Cooper, 7. Anthrax Pandora. Dover, 7 .

Baccha obscuripennis. Banks, Bromley, 6.

Bombylius etenopterus. Dover, 7 .

Criorhina asilica. Flowers, Dareut Wood, 6. berberina. Flowers, Darent Wood, 6 . floccosus. Flower's, Devon, 6. wxyacanthæ. Flowers, Darent Wood, 6. Ranunculi. Flowers, Darent Wood, 6.

Fristalis lunatus. Flags in Ponds, Copenhae'n Fields, 6. Medeterus notatus. Hedges, Copenhagen jïelds, 6. CEstrus pictus. New Forest, Mr. Samouelle, 6. Rhingia campestris. Woods, Norfolk, 6 .

Sericomyia borealis. Flowers, Coomle, and Norwood, 7 . mussitans. Flowers, Darent Wood, 6. 
Tipula nigra. Whittlesea-mere, 6 .

Tropidia milesiformis. Whittlesea-mere, 6.

Volucella inflata. Darent Wood, 6.

OMALOP'TERA.

Hæmobora pallipes. New Forest, Mr. Samouelle, 9 .

\section{ARACHNOIDA.}

Linyphia triangularis.

Micrommata smaragdina. Darent, Mr. Stephens, 6.

Opilio bimaculatus. Battersea Fields.

Oxyopes lineatus? Darent, 6.

Trogulus Næpiformis. Darent, 6.

\section{CRUSTACEA.}

Calliope rupestris. Derwent, Dr. Leach. Gebia stellata. Ditto ditto. Megalopa Bulwerii. Irish Sea, Mr. Bulwer.

Nemertus Nesoides. Derwent, Dr. Leach.

Perimeles denticulatus. Sussex, \&c. Mr. Stephens.

Polybius Henslowii. Welch Coast, Professor Henslow.

Portunus depurator. Devon, \&c. Dr. Leach. emarginatus. Yarmouth.

lividus. Devon, \&c. Dr. Leach. pusillus, ditto. ditto.

THE END.

C, SMITI, PRINTER, ONE BELL YARD, STRAND. 


Books Published by James Bulcock, 163, Strand.

In a neat Foolscap Octavo Volume, Price 7s.

\section{DUTIES OF A. LADY'S MAID.}

With Directions for Conduct, and Numerous Receipts for the Toilette.

Embellished with a beautiful Line Engraving of

BELINDA AT HER TOILETTE.

From Mr. Fradelle's celebrated Picture.

"The remarks upon dressing the hair are equally sensible and just; there is a considerable quantity of instruction and advice, which will render it a useful work both for Ladies, and Ladies" Maids."

Editor of the Literary Gazelte.

In a Neat Foolscap Octavo Volume, Price $6 s$.

WITH A PORTRAIT OF MISS EDGEWORTH.

\section{THE VULGARITIES OF SPEECH CORRECTED.}

In which is shewn the impropriety of Provincial, Vulgar and Cant expressions, used in common conversation. Adapted for the use of Schools and those unacquainted with Grammar.

"The utility of a work of this kind is too evident to require any recommendation. Chesterfield says, "that vulgar expressions imply either a very low turn of mind, or low education, and low company."

Embellished with an Engraving, price 4s. 6d. $12 \mathrm{mo}$.

\section{THE \\ CORRESPONDENT'S ASSISTANT, \\ OR SECRETARY'S GUIDE,}

Being a Selection of Letters adapted to the every-day occurrences of Life. Together with the correct manner of addressing persons in every rank of life, Public Companies, \&c. \&c.

"This is a most useful Book, and we have no doubt that a careful perusal of its contents will benefit the persons for whom it is designed. The information it contains is also valuable."-CR. Rev.

R J. B. respectfully informs the admirers of the Fine Arts, that he has added to his shop a spacious Print Room, where may always be seen on the walls, in Frames, \&c. upwards of Two Hundred of the finest specimens of Engravings after Old and Modern Masters. 